Michał Soćko

Państwowa Wyższa Szkoła Zawodowa w Skierniewicach

\title{
Prawo do obrony w ramach procedury „Niebieskie Karty”
}

\section{The right to defend under the "Blue Cards" procedure}

\begin{abstract}
Abstrakt
Przedmiotem artykułu jest analiza możliwości obrony podejmowanej w ramach procedury „Niebieskie Karty" przez osobę podejrzaną o stosowanie przemocy w rodzinie. We wstępie zarysowano powody wprowadzenia tej procedury na grunt ustawy o przeciwdziałaniu przemocy w rodzinie, w szczególności wskazując na niedoskonałości prawa karnego w badanym zakresie. Dokonano także analizy samej definicji przemocy w rodzinie oraz członka rodziny. W dalszej kolejności omówiono, jakie kroki prawne osoba podejrzana o stosowanie takiej przemocy może podejmować, żeby wykazać niezasadność postawionego jej zarzutu. Jest to o tyle istotne, że samo wszczęcie i prowadzenie procedury „Niebieskie Karty”, a tym bardziej ustalenie stosowania przemocy w rodzinie, może powodować dla osoby podejrzanej liczne, negatywne konsekwencje zarówno natury prawnej, jak i faktycznej. Procedura ta może bowiem bezpośrednio wpływać na takie kwestie jak orzeczenie o winie rozkładu pożycia małżeńskiego, a tym samym na prawo do alimentów, pozbawienia lub ograniczenia praw rodzicielskich, ustalenie i sposób wykonywania kontaktów z dziećmi czy chociażby postrzegania takiej osoby w środowisku zawodowym czy zakładzie pracy.
\end{abstract}

Słowa kluczowe: przemoc w rodzinie, procedura „Niebieskie Karty”, prawo do obrony

\section{Wprowadzenie}

Ustawa o przeciwdziałaniu przemocy w rodzinie (ustawa z dnia 29 lipca 2005 r. o przeciwdziałaniu przemocy w rodzinie, zwana dalej także „u.p.p.r.” lub „ustawą o przeciwdziałaniu przemocy w rodzinie”) weszła w życie 21 listopada 2005 r. Ustawodawca dostrzegł, że stosowane uprzednio mechanizmy prawnokarne nie były wystarczające dla przeciwdziałania skutkom przemocy w rodzinie, jak i zapobieganiu jej w przyszłości (zob.: uzasadnienie projektu ustawy o przeciwdziałaniu przemocy w rodzinie, druk sejmowy nr 3639, Sejm IV kadencji, s. 4 i n.). Do momentu wejścia w życie ustawy o przeciwdziałaniu przemocy w rodzinie podstawowym instrumentem walki z przemocą domową było unormowane w kodeksie karnym (ustawa z dnia 6 czerwca 1997 r. - Kodeks karny, zwany dalej także „k.k.” lub „kodeksem karnym”) przestępstwo znęcania się (art. 207 $\S 1$ k.k.). W brzmieniu $z$ daty uchwalenia ustawy o przeciwdziałaniu przemocy w rodzinie kodeks karny stanowił, że kto znęca się fizycznie lub psychicznie nad osobą najbliższą lub nad inną osobą pozostającą w stałym lub przemijającym stosunku zależności od sprawcy, podlega karze pozbawienia wolności od 3 miesięcy do lat 5 . Dodatkowo przewidziane były dwa typy kwalifikowane, tj. znęcanie się 
ze stosowaniem szczególnego okrucieństwa (art. 207 § 2 k.k.) oraz znęcania się, którego skutkiem jest targnięcie się pokrzywdzonego na własne życie (art. 207 $\S 3$ k.k.) (ustawą z dnia 23 marca 2017 r. o zmianie ustawy - Kodeks Karny, ustawy o postępowaniu w sprawach nieletnich oraz ustawy - kodeks postępowania karnego, dodano do art. 207 k.k. trzeci typ kwalifikowany w postaci znęcania się nad osobą nieporadną ze względu na jej wiek, stan psychiczny lub fizyczny).

Powyższa, prawnokarna konstrukcja znęcania się wykazywała jednak praktyczne słabości zarówno od strony jurydycznej, jak i w aspekcie faktycznym. Przyjęcie przestępstwa znęcania mogło mieć w zasadzie miejsce wówczas, gdy czynności sprawcy miały charakter powtarzalny i były rozciągnięte w dłuższym okresie czasu. Tylko zupełnie wyjątkowo mogło to być zachowanie jednorazowe, przy czym w takim wypadku wymagano znacznej intensywności czynności sprawczej (zob. wyrok Sądu Najwyższego z dnia 8 lutego 1982 r., sygn. akt II KR 5/82, Legalis 22971). W praktyce zatem dopiero wielokrotnie powtarzające się czyny sprawcy (czyny jednostkowe) mogły łącznie być kwalifikowane jako przestępstwo znęcania się.

Co prawda pojedyncze zastosowanie przemocy mogło niekiedy stanowić także inne przestępstwo niż znęcanie się. W szczególności werbalne akty przemocy mogły wyczerpywać znamiona zniewagi (art. 216 k.k.) czy zniesławienia (art. 212 k.k.), a zastosowanie siły fizycznej mogło być kwalifikowane jako tzw. lekki uszczerbek na zdrowiu (art. 157 § 2 k.k.) lub naruszenie nietykalności cielesnej (art. 217 k.k.). Przestępstwa te były jednak ścigane w trybie prywatnoskargowym, a więc wymagały w szerokim zakresie aktywności samego pokrzywdzonego, w tym zwłaszcza wniesienia przez niego prywatnego aktu oskarżenia (art. 157 $\S 2$ k.k. ma nadal zasadniczo charakter prywatnoskargowy, z wyjątkiem sytuacji, gdy pokrzywdzonym jest osoba najbliższa mieszkająca wspólnie ze sprawcą. Zmiana w tym zakresie została wprowadzona ustawą z dnia 10 czerwca 2010 r. o zmianie ustawy o przeciwdziałaniu przemocy w rodzinie oraz niektórych innych ustaw).

Problematyczna była również sama przesłanka znęcania się, która ma charakter pojęcia niedookreślonego i może swoim zakresem obejmować różne sposoby zachowania się sprawcy. Katalog tych zachowań jest otwarty i wymaga każdorazowej wnikliwej oceny stanu faktycznego (Sosnowska, 2008, s. 60). Ponadto czyn ten może być popełniony tylko umyślnie. Sporne natomiast jest, czy może on być popełniony jako dolus directus (zob. wyrok Sądu Apelacyjnego w Krakowie z dnia 20 marca 2012 r., sygn. akt II AKa 32/12, Legalis 527938; wyrok Sądu Najwyższego z dnia 13 września 2005 r., sygn. akt WA 24/05, Legalis 140676; wyrok Sądu Najwyższego z dnia 11 lutego 2003 r., sygn. akt IV KKN 312/99, Legalis 58692; wyrok Sądu Najwyższego z dnia 21 października 1999 r., sygn. akt V KKN 580/97, Legalis 46281), czy może to być także dolus eventualis (zob.: postanowienie Sądu Najwyższego z dnia 23 maja 2017 r., sygn. akt III KK 157/17, Legalis 1657909).

Z drugiej zaś strony zarówno ujawnianiu, jak i pociąganiu sprawcy do odpowiedzialności karnej na podstawie art. 207 k.k. nie ułatwiała szczególna relacja, jaka wiąże go z osobą pokrzywdzoną. Osoby te najczęściej pozostają ze sobą w stałych stosunkach rodzinnych lub w relacjach opartych na stosunku zależności 
(np. podporządkowanie pracodawca-pracownik). Takie uwarunkowania powodują, że ofiary znęcania się mają opory przed składaniem zawiadomienia o podejrzeniu popełnienia przestępstwa (art. $304 \S 1$ ustawy z dnia 6 czerwca $1997 \mathrm{r}$. - Kodeks postępowania karnego, zwanej dalej także „k.p.k.”). A jeżeli nawet postępowanie w takiej sprawie zostanie wszczęte ex officio, nie zawsze współpracują one z organami ścigania, skoro po popełnieniu przestępstwa dalej nierzadko muszą utrzymywać kontakt z podejrzanym czy wręcz z nim zamieszkiwać.

Z uwagi na powyższe pojawiające się problemy oraz konieczność wzmocnienia pozycji prawnej osoby pokrzywdzonej przemocą w rodzinie ustawodawca zdecydował się wydać odrębną ustawę, która miała samodzielnie kwestie te uregulować. Stosownie do uzasadnienia projektu ustawy o przeciwdziałaniu przemocy w rodzinie ustawa ta miała się opierać na następujących założeniach: podkreśleniu, że przemoc $w$ rodzinie jest przestępstwem; odpowiedzialności państwa za zapobieganie i karanie aktów przemocy w rodzinie; odpowiedzialności sprawcy za popełnione przez niego czyny oraz prawie ofiary do bezpieczeństwa (zob.: uzasadnienie projektu ustawy o przeciwdziałaniu przemocy w rodzinie, druk sejmowy nr 3639, Sejm IV kadencji, s. 6). Dla urzeczywistnienie zamierzonych celów na grunt ustawy wprowadzono m.in. definicję przemocy w rodzinie oraz definicję samej rodziny. Określono nadto formy pomocy udzielanej osobie dotkniętej przemocą w rodzinie (art. 3 u.p.p.r.), ograniczenia w kontakcie sprawcy przemocy z osobą pokrzywdzoną (art. 5 u.p.p.r.) czy wreszcie wprowadzono możliwość nakazania sprawcy opuszczenie lokalu (art. 14 u.p.p.r.).

Następnie nowelizacją z dnia 10 czerwca 2010 r. na grunt ustawy o przeciwdziałaniu przemocy w rodzinie została wprowadzona procedura „Niebieskie Karty". Zyskała ona zatem umocowanie w powszechnie obowiązującym akcie prawnym (początkowo procedura ta była unormowana w zarządzeniach Komendanta Głównego Policji, tj. w aktach prawa wewnętrznego; zob. np.: zarządzenie nr 25/98 Komendanta Głównego Policji z dnia 10 listopada 1998 r. w sprawie sposobu przeprowadzania interwencji domowej przez policjantów wobec przemocy w rodzinie pod nazwą „Niebieskie Karty”; szerzej na temat genezy tej procedury: Wrona, 2017, s. 81 i n.). Nowo dodany art. 9d ust. 1 u.p.p.r. stanowił, że podejmowanie interwencji w środowisku wobec rodziny dotkniętej przemocą ma odbywać się właśnie w oparciu o procedurę „Niebieskie Karty”. Jednocześnie art. 9d ust. 5 zawierał upoważnienie dla Rady Ministrów do wydania rozporządzenia precyzującego tę procedurę oraz sporządzenia wzorów odpowiednich formularzy. W wykonaniu powyższego upoważnienia ustawowego zostało wydane rozporządzenie Rady Ministrów z dnia 13 września 2011 r. w sprawie procedury „Niebieskie Karty” oraz wzorów formularzy „Niebieska Karta” (zwane dalej także „rozporządzeniem”; co do wątpliwości na temat powyższego upoważnienia zob. szerzej: Spurek, 2012, s. 148).

Niewątpliwie wszczęcie i prowadzenie procedury „Niebieskie Karty” może powodować wiele niekorzystnych następstw dla osoby podejrzanej o stosowanie przemocy w rodzinie. W związku z tym istotnym zagadnieniem, a zarazem celem niniejszej pracy, jest zbadanie możliwości podejmowania obrony w ramach procedury „Niebieskie Karty”. Przed tym jednak przedstawić należy, jak zdefiniowana została sama przemoc w rodzinie. Przy czym ze względu na to, że przedmiotem 
badania są aktualne rozwiązania prawne, podstawową metodą prowadzenia badań była metoda dogmatyczno-prawna, polegająca na analizie jurydycznej relewantnych przepisów prawnych. Badanie tekstów prawnych zostało wzbogacone w odpowiednim zakresie o zaprezentowanie poglądów doktryny i judykatury.

\section{Przemoc w rodzinie w rozumieniu ustawy}

Ustawa o przeciwdziałaniu przemocy w rodzinie wprowadziła własną definicję legalną przemocy w rodzinie. Została ona zawarta w art. 2 pkt 2 u.p.p.r., który w zakresie pojęcia rodziny odsyła jeszcze do art. 2 pkt 1 u.p.p.r. oraz art. 115 $\S 11$ k.k. Zgodnie z tymi przepisami ilekroć w ustawie jest mowa o przemocy w rodzinie należy przez to rozumieć jednorazowe albo powtarzające się umyślne działanie lub zaniechanie naruszające prawa lub dobra osobiste małżonka, wstępnych, zstępnych, rodzeństwa, powinowatych w tej samej linii lub stopniu, osoby pozostająca w stosunku przysposobienia oraz jej małżonka, osoby pozostającej we wspólnym pożyciu, a także innej osoby wspólnie zamieszkującej lub gospodarującej, w szczególności narażające te osoby na niebezpieczeństwo utraty życia, zdrowia, naruszające ich godność, nietykalność cielesną, wolność, w tym seksualną, powodujące szkody na ich zdrowiu fizycznym lub psychicznym, a także wywołujące cierpienia i krzywdy moralne u osób dotkniętych przemocą (art. 2 pkt 2 u.p.p.r. w zw. z art. 2 pkt 2 u.p.p.r. i art. $115 \S 11$ k.k.). Uzasadnione podejrzenie dokonania takich czynów umożliwia wszczęcie i prowadzenia procedury „Niebieskie Karty”. W związku z tym należy poczynić kilka uwag odnośnie przedmiotowego pojęcia.

Implicite wskazać należy, że dla wypełnienia definicji przemocy w rodzinie - odmiennie niż miało to miejsce w przypadku przestępstwa znęcania się - wystarczy dokonanie choćby jednego czynu o znamionach określonych w art. 2 pkt 2 u.p.p.r. Niemniej jednak mogą to być również czyny powtarzające się, które dopiero poprzez ich pewną systematyczność czy częstotliwość będą mogły wyczerpywać znamiona przemocy. Ustawodawca wymaga jednak, by tego rodzaju czyn lub czyny były popełnione umyślnie. Nie definiuje on jednak na gruncie u.p.p.r. tego ostatniego pojęcia. Wydaje się jednak, że w tym zakresie pomocniczo można sięgnąć do przepisów kodeksu karnego regulujących umyślność (za stanowiskiem takim może przemawiać podobne sformułowanie obydwu ustaw, gdzie jest mowa o „umyślności”, a nie o winie umyślnej. Ponadto w zakresie pojęcia rodziny jest wyraźne odesłanie do przepisów kodeksu karnego, co wskazuje również na ścisły związek ustawy o przeciwdziałaniu przemocy w rodzinie z tą kodyfikacją). Na gruncie kodeksu karnego powyższą kwestię normuje art. $9 \S 1$ k.k., stosownie do którego czyn zabroniony popełniony jest umyślnie, jeżeli sprawca ma zamiar jego popełnienia, to jest chce go popełnić albo przewidując możliwość jego popełnienia, na to się godzi. Przy czym zgodnie z zasadą lege non distinguente nec nostrum est distinguere należałoby dopuścić możliwość dokonania takiego czynu zarówno w zamiarze bezpośrednim, jak i ewentualnym. 
Następnie zauważyć należy, że zachowanie sprawcy może przybrać zarówno formę działania (np. szarpanie, policzkowanie), jak i zaniechania (np. ignorowanie). Najczęściej będzie to jednak działanie. Zachowania takie będą mogły być kwalifikowane jako przemoc domowa, jeżeli naruszają one prawa lub dobra osobiste osób wymienionych w art. 2 pkt 1 u.p.p.r., w szczególności narażające te osoby na niebezpieczeństwo utraty życia, zdrowia, naruszające ich godność, nietykalność cielesną, wolność, w tym seksualną, powodujące szkody na ich zdrowiu fizycznym lub psychicznym, a także wywołujące cierpienia i krzywdy moralne u osób dotkniętych przemocą. W praktyce zatem konkretne czyny stanowiące przemoc w rodzinie mogą zarazem wyczerpywać znamiona przestępstw, np. zabójstwa (art. 148 k.k.), zgwałcenia (art. 197 k.k.), rozboju (art. 280 k.k.), bezprawnego przerwania ciąży (art. 153 k.k.), znęcania się (art. 207 k.k.), zniesławienia (art. 212 k.k.), znieważenia (art. 216 k.k.), naruszenia nietykalności cielesnej (art. 217 k.k.). W takich przypadkach ustawodawca nakłada szczególny obowiązek na osoby, które w związku z wykonywaniem swoich obowiązków służbowych lub zawodowych powzięły podejrzenie o popełnieniu ściganego z urzędu przestępstwa z użyciem przemocy w rodzinie. Osoby te są zobligowane do niezwłocznego zawiadomienia o tym fakcie policji lub prokuratora (art. 12 ust. 1 u.p.p.r.). Podobny obowiązek mają również osoby będące świadkami przemocy w rodzinie. Powinny one zawiadomić policję, prokuratora lub inny podmiot działający na rzecz przeciwdziałania przemocy w rodzinie o takich sytuacjach (art. 12 ust. 2 u.p.p.r.).

Czynność sprawcy przemocy w rodzinie, choć może, to jednak w danym wypadku nie musi jednocześnie stanowić przestępstwa. Wynika to z faktu, że ustawa o przeciwdziałaniu przemocy w rodzinie wprowadza własną definicję przemocy w rodzinie („ilekroć w ustawie jest mowa o przemocy w rodzinie należy przez to rozumieć [...]”), niezależną od innych czynów zabronionych. Co więcej katalog zachowań, które mogą stanowić przemoc w rodzinie, jest katalogiem otwartym, przykładowym. Świadczy o tym ustawowy zwrot „w szczególności” zawarty w art. 2 pkt 2 u.p.p.r. Zabieg taki jest prawidłowy, gdyż nie da się a priori wyartykułować wszystkich przypadków stosowania przemocy w rodzinie. Jednakże w formularzu „Niebieska Karta” - D, stanowiącym załącznik do rozporządzenia w sprawie procedury „Niebieskie Karty”, wymieniono niektóre (jak się wydaje - typowe) formy przemocy w rodzinie. W zakresie przemocy fizycznej wskazano na: popychanie, uderzanie, wykręcanie rąk, duszenie, kopanie, spoliczkowanie, w tym powodujące zasinienia, zadrapania, krwawienia i oparzenia. W odniesieniu do przemocy psychicznej expressis verbis wskazano na: izolowanie, wyzywanie, ośmieszanie, grożenie, kontrolowanie, ograniczanie kontaktów, krytykowanie, poniżanie, demoralizację czy ciągłe niepokojenie. Odrębnie zaś wymieniona został przemoc seksualna, w tym zmuszanie do obcowania płciowego czy innych czynności seksualnych. Co jednak ciekawe, w formularzu tym przewidziano także niszczenie lub uszkadzanie mienia, które tylko pośrednio może oddziaływać na osobę najbliższą.

Osobnego zastanowienia wymaga kwestia czy przemocą w rodzinie może być także tzw. przemoc ekonomiczna. Definicja przemocy w rodzinie verba legis takiej formy przemocy nie wymienia, co jednak ze względu na otwarty katalog takich czynów nie musi mieć miejsca. Nadmienić jednak należy, że o przemocy 
ekonomicznej wspomina Konwencja o zapobieganiu i zwalczaniu przemocy wobec kobiet i przemocy domowej sporządzona w Stambule dnia 11 maja 2011 r. (zwana dalej „konwencją”), która została - z pewnymi wyjątkami - przez Polskę ratyfikowana (zob.: ustawa z dnia 6 lutego 2015 r. o ratyfikacji Konwencji Rady Europy o zapobieganiu i zwalczaniu przemocy wobec kobiet i przemocy domowej, sporządzonej w Stambule dnia 11 maja 2011 r.). Konwencja ta definiuje przemoc domową jako wszelkie akty przemocy fizycznej, seksualnej, psychologicznej lub ekonomicznej zdarzające się w rodzinie lub gospodarstwie domowym, lub między byłymi lub obecnymi małżonkami lub partnerami, niezależnie od tego, czy sprawca i ofiara dzielą lub dzielili miejsce zamieszkania, czy nie (art. 3 lit. b konwencji). Wyraźnie zatem została wymieniona przemoc ekonomiczna, co polski ustawodawca zaakceptował poprzez akt ratyfikacji. W konsekwencji przyjąć można, że prawodawca, włączając konwencję do polskiego porządku, dopuścił możliwość ochrony pokrzywdzonych także przed tego rodzaju działaniami. Nie ma zatem powodów, by spod definicji przemocy w rodzinie wyłączać przemoc ekonomiczną, o ile będzie ona w konkretnym przypadku spełniała przesłanki wskazane w art. 2 pkt 2 u.p.p.r.

W tym kontekście dodać należy, że mogą się pojawiać praktyczne problemy z ustaleniem, w jakich dokładnie przypadkach mamy do czynienia z przemocą ekonomiczną. Nie ma bowiem w tym zakresie żadnej definicji legalnej, a powyższa konwencja o takiej formie przemocy jedynie wspomina bez jej precyzowania. W literaturze zaś zagadnienie to jest różnie ujmowane. Tytułem przykładu wskazać można, że o przemocy ekonomicznej można mówić „wtedy, gdy jej sprawca używa pieniędzy albo innych wartości materialnych do zaspokojenia potrzeby władzy i kontroli partnera lub przerzuca na niego odpowiedzialność za koszty utrzymania domu. Sprawca wykorzystuje uzależnienie partnera od swoich dochodów lub majątku do znęcania się" (Tracz-Dal, 2015, s. 3). Z kolei M. Zając definiuje to pojęcie jako „ogół działań mających na celu całkowite uzależnienie finansowe ofiary od sprawcy przez zabranianie jej podjęcia pracy zarobkowej, utrudnianie aktywności zawodowej i konieczność pozostawania na wyłącznym utrzymaniu [«łasce i niełasce»] partnera lub opiekuna prawnego" (Zając, 2012, s. 18-19; w zakresie przemocy ekonomicznej zob. także: Ksieniewicz, 2013, s. 43 i n.).

Analizę definicji przemocy w rodzinie zakończyć należy na aspektach podmiotowych. Ustawodawca wyraźnie bowiem zaznacza, że w unormowaniu tym nie chodzi o jakąkolwiek przemoc, a tylko taką, która ma miejsce w rodzinie. $Z$ tego punktu widzenia istotne jest, pomiędzy jakimi osobami dochodzi do aktów przemocy. Katalog tych osób wskazuje art. 2 pkt 1 u.p.p.r., przy czym częściowo odsyła on do art. $115 \S 11$ k.k. określającego osobę najbliższą. W konsekwencji za członków rodziny w rozumieniu powyższych przepisów należy uznać małżonka, wstępnych, zstępnych, rodzeństwo, powinowatych w tej samej linii lub stopniu, osoby pozostające w stosunku przysposobienia oraz ich małżonkowie, osoby pozostająca we wspólnym pożyciu (art. 115 § 11 k.k.) oraz inne osoby wspólnie zamieszkujące lub gospodarujące (art. 2 pkt 1 u.p.p.r. in fine). O ile jednak podmioty wyliczone w art. 115 § 11 k.k. nie budzą większej wątpliwości, gdyż są one powiązane więzami pokrewieństwa, powinowactwa czy też pozostają w stałym pożyciu (np. konkubenci), o tyle wskazanie wprost w ustawie, że członkami 
rodziny są także inne osoby wspólnie zamieszkujące lub gospodarujące budzi pewne wątpliwości. W praktyce bowiem mogą to być osoby, których nie łączy żadna więź prawnorodzinna ani nawet stałe pożycie, a jedynie z przyczyn wyłącznie faktycznych razem zamieszkują czy gospodarują (np. studenci w akademiku). Wydaje się, że zaliczenie tych osób do grona członków rodziny nazbyt odbiega od potocznego rozumienia rodziny i nie znajduje wystarczającego uzasadnienia w ratio legis (zob. Dudka, 2006, s. 44; Kiełtyka i Ważny, 2015, s. 37). W tych bowiem przypadkach zazwyczaj nie zachodzą specyficzne trudności, które legły u podstaw wprowadzenia ustawy o przeciwdziałaniu przemocy w rodzinie (np. istnienie więzi emocjonalnej czy konieczności wspólnego zamieszkiwania) oraz procedury „Niebieskie Karty”.

\section{Prawo do obrony w ramach procedury „Niebieskie Karty”}

Wszczęcie i prowadzenie procedury „Niebieskie Karty” może powodować dla osoby podejrzanej o stosowanie przemocy w rodzinie szereg negatywnych konsekwencji. Skutki te mogą dotyczyć zarówno sfery prawnej, jak i pozaprawnej. Tytułem przykładu można wskazać, że prowadzenie przedmiotowej procedury może rzutować na kwestie okołorozwodowe (orzeczenie o winie rozkładu pożycia małżeńskiego, o kontaktach z dziećmi czy o ograniczeniu lub pozbawieniu władzy rodzicielskiej), jak również na możliwość nakazania opuszczenia mieszkania, choćby stanowiło ono przedmiot wyłącznej własności sprawcy. Samo już nawet wszczęcie procedury „Niebieskie Karty” może wywołać dla osoby podejrzanej o stosowanie przemocy szczególnie negatywne konsekwencje, zwłaszcza gdy osoba taka zajmuje stanowiska lub pełni funkcje publiczne, czy też wykonuje zawody zaufania publicznego. W opinii społecznej już wszczęcie takiej procedury odbierane jest zdecydowanie pejoratywnie, a przecież do jego zainicjowania wystarczy tylko uzasadnione podejrzenie stosowania przemocy w rodzinie, a nie pewność.

W tym kontekście zauważyć również należy, że ze względu na bardzo szeroki zakres przedmiotowy czynów, które mogą stanowić przemoc domową w rozumieniu art. 2 pkt 2 u.p.p.r., jak również fakt, że dla zainicjowania procedury „Niebieskie Karty” wystarczy jedynie uzasadnione podejrzenie jej stosowania, to regulacja ta może być instrumentalnie wykorzystywane przez osoby najbliższe pozostające ze sobą w konflikcie. Nierzadko zdarza się wręcz, że pełnomocnicy procesowi jeszcze przed wystąpieniem z powództwem rozwodowym doradzają stronie zainicjowanie procedury „Niebieskie Karty”. W związku z powyższym istotnym zagadnieniem staje się kwestia przeciwdziałania bezzasadnym lub fałszywym zgłoszeniom stosowania przemocy w rodzinie.

Nieprawidłowości na gruncie analizowanej procedury nie muszą jednak koniecznie wynikać z intencjonalnego działania członka rodziny. Mogą one być spowodowane także nieprawidłowym działaniem funkcjonariuszy współdziałających przy realizacji procedury „Niebieskie Karty” czy też samych członków zespołu interdyscyplinarnego. Uchybienia takie mogą przejawiać się choćby we wszczęciu procedury mimo braku uzasadnionego podejrzenia stosowania przemocy 
w rodzinie, braku umyślności po stronie sprawcy, nieprawidłowego wypełnienia „Niebieskich Kart” czy niezakończenia procedury mimo ustania aktów przemocy. W takich sytuacjach osobie podejrzanej może zależeć na wykazaniu, że nie stosowała ona w ogóle przemocy w rodzinie lub jej czyny nie mogą być kwalifikowane jako przemoc w rozumieniu art. 2 pkt 2 u.p.p.r., ewentualnie, że zaprzestała jej stosowania (zob.: $§ 18$ ust. 1 pkt 1 rozporządzenia), a tym samym na jak najszybszym zakończeniu prowadzonego postępowania.

Jednakże w ramach samej procedury „Niebieskie Karty” osoba podejrzana o stosowanie przemocy w rodzinie będzie miała znacznie ograniczoną możliwość obrony swoich praw. Zasadniczo bowiem będzie ona uprawniona do złożenia wyjaśnień dopiero podczas posiedzenia zespołu interdyscyplinarnego. Przy czym składane wyjaśnienia będą służyły w pierwszej kolejności wypełnieniu formularza „Niebieska Karta - D”. Niemniej jednak członkowie zespołu interdyscyplinarnego powinni także z urzędu podjąć działania w celu zdiagnozowania sytuacji rodziny, co do której istnieje podejrzenie, że jest dotknięta przemocą (zob.: § 17 ust. 3 pkt 1 rozporządzenia). W tym zakresie, jak się wydaje, powinni oni także rozważyć, czy do aktów przemocy w ogóle doszło, a jeśli tak, to czy mogą być one kwalifikowane jako przemoc w rodzinie w rozumieniu ustawy.

Zasadnicze jednak znaczenie dla możliwości podejmowania obrony przez podejrzanego o stosowanie przemocy w rodzinie będzie miało to, czy służyć mu będą jakiekolwiek środki zaskarżenia w stosunku do czynności lub rozstrzygnięć podejmowanych w ramach przedmiotowej procedury. W tym zakresie w pierwszej kolejności ustalić należy charakter prawny procedury „Niebieskie Karty”. Z art. 9d ust. 2 u.p.p.r. wynika, że obejmuje ona ogół czynności podejmowanych i realizowanych przez przedstawicieli jednostek organizacyjnych pomocy społecznej, gminnych komisji rozwiązywania problemów alkoholowych, policji, oświaty i ochrony zdrowia, w związku z uzasadnionym podejrzeniem zaistnienia przemocy w rodzinie. Wszczynana jest ona poprzez wypełnienie formularza „Niebieska Karta - A", a następnie zasadnicze czynności dokonywane są przed zespołem interdyscyplinarnym, o którym mowa w art. 9a u.p.p.r.

Podkreślić przy tym należy, że procedura „Niebieskie Karty” ma charakter samodzielny. Została ona bowiem kompleksowo uregulowana w ustawie o przeciwdziałaniu przemocy w rodzinie oraz - w wydanym na jej podstawie - rozporządzeniu Rady Ministrów z dnia 13 września 2011 r. w sprawie procedury „Niebieskie Karty” oraz wzorów formularzy „Niebieska Karta”. Natomiast tryb i sposób powoływania i odwoływania członków zespołu interdyscyplinarnego oraz szczegółowe warunki jego funkcjonowania powinny zostać doprecyzowane w uchwale właściwej rady gminy. Na gruncie tych przepisów nie zamieszczono jednak żadnego ogólnego odesłania do procedury karnej, cywilnej czy administracyjnej, co mogłoby sugerować, jaki jest charakter prawny tej regulacji.

Ze względu jednak na to, jakie podmioty wszczynają i prowadzą to postepowanie, mogłoby się wydawać, że jest to sui generis postępowanie administracyjne, a w konsekwencji osobie podejrzanej mogłyby przysługiwać środki zaskarżenia przewidziane w kodeksie postępowania administracyjnego (ustawa z dnia 14 czerwca 1960 r. - Kodeks postępowania administracyjnego, zwana dalej także „k.p.a.”) oraz w prawie o postępowaniu przed sądami administracyjnymi 
(ustawa z dnia 30 sierpnia 2002 r. - Prawo o postępowaniu przed sądami administracyjnymi, zwana dalej także „p.p.s.a.”). Jednakże orzecznictwo sądowe od początku obowiązywania ustawy o przeciwdziałaniu przemocy w rodzinie stało na stanowisku, że czynności podejmowane przez zespół interdyscyplinarny nie mogą być przedmiotem sądowoadministracyjnej kontroli, $w$ tym także na podstawie art. $3 \S 2$ pkt 4 p.p.s.a. (zob.: postanowienie Naczelnego Sądu Administracyjnego z dnia 25 listopada 2015 r., sygn. akt I OSK 2896/15; postanowienie Wojewódzkiego Sądu Administracyjnego w Bydgoszczy z dnia 8 maja 2015 r., sygn. akt II SA/Bd 376/15; por. także: postanowienie Wojewódzkiego Sądu Administracyjnego w Gorzowie Wielkopolskim z dnia 13 grudnia 2013 r., sygn. akt II SA/Go 883/13; wyrok Wojewódzkiego Sądu Administracyjnego we Wrocławiu z dnia 14 października 2014 r., sygn. akt IV SAB/Wr 166/14).

W judykaturze przyjmowano na ogół, że zespół interdyscyplinarny nie jest organem administracji publicznej ani w znaczeniu ustrojowym, ani w znaczeniu funkcjonalnym (inaczej: postanowienie Naczelnego Sądu Administracyjnego z dnia 25 listopada 2015 r., sygn. akt I OSK 2896/15, w którym przyjęto, że stanowi on jednak organ administracji w znaczeniu funkcjonalnym, ale jego czynności nie podlegają kognicji sądów administracyjnych), gdyż nie posiada on żadnych kompetencji władczych, w szczególności prawa do wydawania decyzji administracyjnych, postanowień lub innych aktów lub czynności dotyczących uprawnień lub obowiązków wynikających z przepisów prawa. Wszystkie zaś działania podejmowane przez zespół interdyscyplinarny należą do sfery działań prawnych niewładczych, nie zmierzają wprost do wywołania skutków prawnych i nie mogą być wprowadzane w życie za pomocą przymusu bezpośredniego. W powyższym postanowieniu Naczelnego Sądu Administracyjnego z dnia 25 listopada 2015 r. podkreślono, że „analiza kompetencji powierzonych zespołowi interdyscyplinarnemu [...] wskazuje, że ograniczają się one wyłącznie do funkcji integrujących, koordynacyjnych i organizujących współdziałanie wymienionych przez ustawodawcę podmiotów" (postanowienie Naczelnego Sądu Administracyjnego z dnia 25 listopada 2015 r., sygn. akt I OSK 2896/15).

W najnowszym orzecznictwie sądowoadministracyjnym powyższe, ugruntowane stanowisko zostało zakwestionowane. Mianowicie w postanowieniu Wojewódzkiego Sądu Administracyjnego w Poznaniu z dnia 14 czerwca 2017 r. (postanowienie Wojewódzkiego Sądu Administracyjnego w Poznaniu z dnia 14 czerwca 2017 r., sygn. akt II SAB/Po 87/17) expressis verbis wskazano, że

czynności (lub ich brak) podejmowane przez zespół interdyscyplinarny, jako dotyczące wynikających z przepisów prawa uprawnień lub obowiązków uczestników tego postępowania, mogą być poddane kontroli sądowoadministracyjnej, gdyż stanowią czynności, o których mowa w art. 3 § 2 pkt 4 Prawa o postępowaniu przed sądami administracyjnymi. Brak jest przeszkód, by strona poddała kontroli sądowoadministracyjnej czynności zespołu interdyscyplinarnego zakończenia procedury „Niebieskie Karty" (postanowienie Wojewódzkiego Sądu Administracyjnego w Poznaniu z dnia 14 czerwca 2017 r., sygn. akt II SAB/Po 87/17).

Sąd ten w przytoczonym orzeczeniu zwrócił uwagę, że z przepisów u.p.p.r. wynika, że osoba dotknięta przemocą w rodzinie [...] posiada - w zależności od stanu sprawy - w ramach procedury „Niebieskie Karty” szereg wynikających 
z przepisów prawa uprawnień. Zgodnie z art. 3 ust. 1 u.p.p.r. osobie takiej udziela się bezpłatnej pomocy, w szczególności: 1) poradnictwa medycznego, psychologicznego, prawnego, socjalnego, zawodowego i rodzinnego; 2) interwencji kryzysowej i wsparcia; 3) ochrony przed dalszym krzywdzeniem, przez uniemożliwienie osobom stosującym przemoc korzystania ze wspólnie zajmowanego z innymi członkami rodziny mieszkania oraz zakazanie kontaktowania się i zbliżania się do osoby pokrzywdzonej; 4) zapewnienia osobie dotkniętej przemocą w rodzinie bezpiecznego schronienia w specjalistycznym ośrodku wsparcia dla ofiar przemocy w rodzinie; 5) badania lekarskiego w celu ustalenia przyczyn i rodzaju uszkodzeń ciała związanych z użyciem przemocy w rodzinie oraz wydania zaświadczenia lekarskiego w tym przedmiocie; 6) zapewnienia osobie dotkniętej przemocą w rodzinie, która nie ma tytułu prawnego do zajmowanego wspólnie ze sprawcą przemocy lokalu, pomocy w uzyskaniu mieszkania (podobnie przyjmuje M. Czarkowska wskazując, że „zarówno zespoły interdyscyplinarne, jak i grupy robocze mają konkretne obowiązki w ramach procedury "Niebieskie Karty», które określa m.in. § 16 ust. 1 rozporządzenia" (zob.: Czarkowska, 2014, s. 106).

Z kolei na osobie stosującej przemoc w rodzinie - jak wskazano w powyższym orzeczeniu - w związku ze wszczęciem procedury „Niebieskie Karty” ciążą określone obowiązki. Przepis art. 4 u.p.p.r. określa, że wobec osób stosujących przemoc w rodzinie stosuje się przewidziane w ustawie środki mające na celu zapobieganie ich kontaktowaniu się z osobami pokrzywdzonymi oraz oddziaływania korekcyjno-edukacyjne. I tak m.in. zespół interdyscyplinarny ma prawo do inicjowania działań w stosunku do osób stosujących przemoc w rodzinie (art. 9b ust. 2 pkt 5 u.p.p.r.). W ramach tej procedury przykładowo funkcjonariusz policji przeprowadza, o ile jest to możliwe, z osobą, wobec której istnieje podejrzenie, że stosuje przemoc w rodzinie, rozmowę, w szczególności o odpowiedzialności karnej za znęcanie się fizyczne lub psychiczne nad osobą najbliższą lub inną osobą pozostającą w stałym lub przemijającym stosunku zależności od osoby, wobec której istnieje podejrzenie, że stosuje przemoc w rodzinie, albo nad małoletnim lub osobą nieporadną ze względu na jej stan psychiczny lub fizyczny, oraz wzywa osobę, wobec której istnieje podejrzenie, że stosuje przemoc w rodzinie, do zachowania zgodnego z prawem i zasadami współżycia społecznego (§ 13 pkt 4 rozporządzenia), a członkowie zespołu interdyscyplinarnego lub grupy roboczej podejmują działania w stosunku do osoby, wobec której istnieje podejrzenie, że stosuje przemoc w rodzinie, w celu zaprzestania stosowania tego rodzaju zachowań (§ 16 pkt 2 rozporządzenia). Ponadto zgodnie z § 17 ust. 4 rozporządzenia jeżeli osoba, wobec której istnieje podejrzenie, że stosuje przemoc w rodzinie, nadużywa alkoholu, członkowie zespołu interdyscyplinarnego lub grupy roboczej kierują tę osobę do gminnej komisji rozwiązywania problemów alkoholowych.

W konsekwencji - jak wywiódł Wojewódzki Sąd Administracyjny w Poznaniu - z powołanych przepisów jasno wynika, że w ramach procedury „Niebieskie Karty” osobom dotkniętym przemocą w rodzinie przysługują ujęte przepisami uprawnienia, zaś na osobach stosujących przemoc ciążą konkretne obowiązki. Wobec tego przyjąć należy, że czynności (lub ich brak) podejmowane przez zespół interdyscyplinarny, jako dotyczące wynikających z przepisów prawa uprawnień 
lub obowiązków uczestników tego postępowania, mogą być poddane kontroli sądowoadministracyjnej, gdyż stanowią czynności, o których mowa w art. 3 § 2 pkt 4 p.p.s.a.

Aktualnie trudno jednak przesądzić, czy powyższe rozstrzygnięcie będzie stanowiło jedynie jednostkowy wyjątek od dotychczas ugruntowanego stanowiska judykatury, czy też zapoczątkuje nową linię orzeczniczą w tym zakresie. W każdym razie dopuszczenie nawet sądowoadministracyjnej kontroli nad czynnościami dokonywanymi w ramach procedury „Niebieskie Karty” nie będzie rozwiązywało wszystkich pojawiających się problemów związanych $-\mathrm{w}$ istocie $-\mathrm{z}$ brakiem skutecznych środków zaskarżenia. Sądy administracyjne nie rozstrzygają bowiem zasadniczo spraw in meriti, a jedynie dokonują kontroli od strony formalnoprawnej. W razie zaś dostrzeżenia uchybień uchylają zaskarżone rozstrzygnięcie lub czynność (model kasatoryjny). Stąd też podjęcie obrony w ramach postępowania sądowoadministracyjnego będzie mogło nastąpić tylko w ograniczonym zakresie, o ile w ogóle - ze względu na obowiązującą linię orzeczniczą - skarga taka zostanie przyjęta do rozpoznania.

Gdyby natomiast zarzucany osobie podejrzanej o stosownie przemocy w rodzinie czyn mógł stanowić zarazem przestępstwo, to wówczas mogłaby ona realizować swoje prawo do obrony na gruncie procedury karnej. W przypadku bowiem podejrzenia popełnienia przestępstwa zespół interdyscyplinarny przekazuje akta sprawy właściwym organom postępowania przygotowawczego ( $§ 10$ ust. 2 rozporządzenia). Wówczas podejrzany mógłby w pełni realizować swoje prawo do obrony, chociażby korzystając z domniemania niewinności, zasady in dubio pro reo czy też z prawa do milczenia. Jednakże i w tym wypadku mogą pojawić się praktyczne problemy, które swoje źródło mają w definicji przemocy w rodzinie z jednej strony, a z drugiej strony w samodzielności procedury „Niebieskie Karty". Przemoc w rodzinie nie musi bowiem stanowić zarazem konkretnego przestępstwa. Jest to pojęcie o otwartym katalogu czynów, podczas gdy przestępstwo musi być dokładnie w ustawie opisane (nullum crimen sine lege). Poza tym przesłanki podejmowania czynności w ramach procedury „Niebieskie Karty" nie pokrywają się z warunkami odpowiedzialności karnej. W związku z tym nie jest wykluczona sytuacja, że ten sam czyn może uzasadniać uniewinnienie na gruncie prawa karnego, a jednocześnie stanowić przemoc domową w rozumieniu ustawy o przeciwdziałaniu przemocy w rodzinie (np. brak powtarzalności przy przestępstwie znęcania się).

\section{Podsumowanie}

De lege lata możliwości podejmowania obrony na gruncie procedury „Niebieskie Karty" są mocno ograniczone. W istocie osoba podejrzana o stosowanie przemocy domowej nie dysponuje nawet skutecznymi środkami zaskarżenia umożliwiającymi weryfikowanie czynności i rozstrzygnięć dokonywanych w toku tego postępowania. Orzecznictwo sądowoadministracyjne przyjmuje bowiem na ogół, że $w$ tego rodzaju sprawach skarga do wojewódzkiego sądu administracyjnego 
nie przysługuje. Judykatura uzasadnia takie stanowisko tym, że zespół interdyscyplinarny, przed którym toczy się ta procedura, nie jest organem administracji publicznej i nie podejmuje on władczych rozstrzygnięć, a przez to podejmowane przez niego działania nie mogą być kwalifikowane jako akty lub czynności z zakresu administracji publicznej dotyczące uprawnień lub obowiązków wynikających z przepisów prawa w rozumieniu art. $3 \S 2$ pkt 4 p.p.s.a.

Wobec powyższego obrona praw osoby podejrzanej o stosowanie przemocy w rodzinie ipso facto musi być realizowana na gruncie innych regulacji prawnych, o ile w danym przypadku będzie to możliwe. Na okoliczność tę zwrócił uwagą Naczelny Sąd Administracyjny wskazując, że brak możliwości wniesienia skargi w postępowaniu sądowoadministracyjnym

nie pozbawia [...] skarżącego prawa do sądu. Prawa i obowiązki skarżącego będą kształtowane w ramach postępowań regulowanych odrębnymi ustawami - przed wysoko wyspecjalizowanymi organami państwowymi - Sądem Rodzinnym (KPC, kro [...]) bądź Prokuratorem a następnie - ewentualnie - Sądem powszechnym (KPK, KK; [...]). W każdym z tych postępowań skarżący korzystać będzie z prawa do obrony (postanowienie Naczelnego Sądu Administracyjnego z dnia 25 listopada 2015 r., sygn. akt I OSK 2896/15).

W szczególności gdyby zarzucany czyn mógł stanowić zarazem przestępstwo, to w toczącym się postępowaniu karnym podejrzany mógłby podejmować środki obronne mające znaczenie dla jednego, ale i drugiego postępowania (np. poprzez korzystanie z inicjatywy dowodowej, w tym zwłaszcza doprowadzenia do przesłuchania stron lub interweniujących funkcjonariuszy policji albo ewentualnej konfrontacji etc.). Nie zawsze jednak w praktyce będzie to możliwe ze względu na fakt, że przemoc domowa nie musi stanowić każdorazowo przestępstwa. Inne są przy tym także przesłanki prowadzenia procedury „Niebieskie Karty”, a inne są warunki odpowiedzialności karnej.

Ostatecznie gdyby wszczęcie i prowadzenie procedury „Niebieskie Karty” nastąpiło na skutek nieuzasadnionego czy fałszywego zawiadomienia o stosowaniu przemocy w rodzinie, a zarzutu tego nie można byłoby zweryfikować w innym trybie, to osobie podejrzanej będzie przysługiwało powództwo o ochronę dóbr osobistych (zob.: art. 23 i art. 24 ustawy z dnia 23 kwietnia 1964 r. - Kodeks cywilny, zwanej dalej także „k.c.”). W szczególności z powołaniem się na naruszenie dobrego imienia, czci lub godności. Niezależnie od tego możliwe byłoby również wystąpienie z prywatnym aktem oskarżenia opartym na zarzucie zniesławienia (art. 212 k.k.).

\section{Bibliografia}

Czarkowska M. (2014), Przeciwdziałanie przemocy wobec kobiet w rodzinie w praktyce organów ścigania, wymiaru sprawiedliwości i innych instytucji, LexisNexis, Warszawa,

Dudka K. (2006), Środki zapobiegawcze stosowane wobec sprawców przemocy w rodzinie, „Wojskowy Przegląd Prawniczy" 2, s. 44-48.

Kiełtyka A., Ważny A. (2015), Przeciwdziałanie przemocy w rodzinie. Komentarz, Wolters Kluwer, Warszawa. 
Mazowiecka L. (red.) (2013), Jak skutecznie chronić ofiary przemocy w rodzinie, Wolters Kluwer, Warszawa.

Sosnowska J.D. (2008), Przestępstwo znęcania się, „Państwo i Prawo” 3, s. 60-71.

Spurek S. (2012), Przeciwdziałanie przemocy w rodzinie. Komentarz, Wolters Kluwer, Warszawa.

Tracz-Dal J. (2015), Przemoc ekonomiczna, Kancelaria Senatu, Warszawa.

Wrona G. (2017), Konflikt a przemoc. Zastosowanie art. $207 \S 1$ k.k. w przeciwdziałaniu przemocy w rodzinie, Pracownia Poligraficzna „Duet”, Warszawa.

Zając M. (2012), Procedura „Niebieskie Karty”. Realizacja zadań w zakresie przeciwdziałania przemocy $w$ rodzinie, Presscom sp. z o.o., Wrocław.

\section{Akty prawne}

Konwencja Rady Europy o zapobieganiu i zwalczaniu przemocy wobec kobiet i przemocy domowej, sporządzona w Stambule dnia 11 maja $2011 \mathrm{r}$.

Rozporządzenie Rady Ministrów z dnia 13 września 2011 r. w sprawie procedury „Niebieskie Karty” oraz wzorów formularzy „Niebieska Karta” (Dz.U. z 2011 r. Nr 209, poz. 1245).

Ustawa z dnia 10 czerwca 2010 r. o zmianie ustawy o przeciwdziałaniu przemocy w rodzinie oraz niektórych innych ustaw (Dz.U. z 2010 r. Nr 125, poz. 842).

Ustawa z dnia 14 czerwca 1960 r. - Kodeks postępowania administracyjnego (tj. Dz.U. z 2018 r., poz. 2096).

Ustawa z dnia 23 kwietnia 1964 r. - Kodeks cywilny (t.j. Dz.U. z 2018 r., poz. 1025 ze zm.).

Ustawa z dnia 23 marca 2017 r. o zmianie ustawy - kodeks karny, ustawy o postępowaniu w sprawach nieletnich oraz ustawy - kodeks postępowania karnego (Dz.U. z 2017 r., poz. 773).

Ustawa z dnia 29 lipca 2005 r. o przeciwdziałaniu przemocy w rodzinie (tj. Dz.U. z 2015 r., poz. 1390).

Ustawa z dnia 30 sierpnia 2002 r. Prawo o postępowaniu przed sądami administracyjnymi (t.j. Dz.U. z 2018 r., poz. 1302 ze zm).

Ustawa z dnia 6 czerwca 1997 r. - Kodeks karny (tj. Dz.U. z 2018 r., poz. 1600).

Ustawa z dnia 6 czerwca 1997 r. - Kodeks postępowania karnego (tj. Dz.U. z 2018 r., poz. 1987 ze zm.).

Ustawa z dnia 6 lutego 2015 r. o ratyfikacji Konwencji Rady Europy o zapobieganiu i zwalczaniu przemocy wobec kobiet i przemocy domowej, sporządzonej w Stambule dnia 11 maja 2011 r. (Dz.U. z 2015 r., poz. 398).

Uzasadnienie projektu ustawy o przeciwdziałaniu przemocy w rodzinie, druk sejmowy $\mathrm{nr} 3639$, Sejm IV kadencji.

Zarządzenie nr 25/98 Komendanta Głównego Policji z dnia 10 listopada 1998 r. w sprawie sposobu przeprowadzania interwencji domowej przez policjantów wobec przemocy w rodzinie pod nazwą „Niebieskie Karty” (Dz.Urz. KGP Nr 7, poz. 37).

\section{Orzecznictwo}

Postanowienie Naczelnego Sądu Administracyjnego z dnia 25 listopada 2015 r., sygn. akt I OSK 2896/15, Legalis 1386921.

Postanowienie Sądu Najwyższego z dnia 23 maja 2017 r., sygn. akt III KK 157/17, Legalis 1657909.

Postanowienie Wojewódzkiego Sądu Administracyjnego w Bydgoszczy z dnia 8 maja 2015 r., sygn. akt II SA/Bd 376/15, Legalis 127756.

Postanowienie Wojewódzkiego Sądu Administracyjnego w Gorzowie Wielkopolskim z dnia 13 grudnia 2013 r., sygn. akt II SA/Go 883/13, Legalis 947518.

Postanowienie Wojewódzkiego Sądu Administracyjnego w Poznaniu z dnia 14 czerwca 2017 r., sygn. akt II SAB/Po 87/17, Legalis 1654118.

Wyrok Sądu Apelacyjnego w Krakowie z dnia 20 marca 2012 r., sygn. akt II AKa 32/12, Legalis 527938.

Wyrok Sądu Najwyższego z dnia 11 lutego 2003 r., sygn. akt IV KKN 312/99, Legalis 58692.

Wyrok Sądu Najwyższego z dnia 13 września 2005 r., sygn. akt WA 24/05, Legalis 140676.

Wyrok Sądu Najwyższego z dnia 21 października 1999 r., sygn. akt V KKN 580/97, Legalis 46281.

Wyrok Sądu Najwyższego z dnia 8 lutego 1982 r., sygn. akt II KR 5/82, Legalis 22971.

Wyrok Wojewódzkiego Sądu Administracyjnego we Wrocławiu z dnia 14 października 2014 r., sygn. akt IV SAB/Wr 166/14, Legalis 1195181. 


\begin{abstract}
The subject matter of this article is the analysis of the right to defense within the framework of the "Blue Cards" procedure, by a person suspected of using domestic violence. Firstly, the reasons for introducing this procedure into the Act on Counteracting Domestic Violence are described, with emphasis on the flaws of criminal law in the examined area. Secondly, an analysis of the definition of domestic violence and family member is performed. Thirdly, this article discusses the legal steps a person suspected of violence can take to prove his/her innocence of the allegation. This issue is very important since the initiation and conduct of the "Blue Cards" procedure and, even more so, the proof of domestic violence, can cause a number of negative consequences for the suspect, both legal and factual. This procedure may directly affect issues such as the ruling on whether and which spouse is at fault for the breakdown of marriage, and thus the right to maintenance, deprivation or limitation of parental rights, determination and manner of contacts with children or even the perception of a person in the professional environment or workplace.
\end{abstract}

Keywords: domestic violence, the "Blue Cards" procedure, the right to defense 